\title{
Intertextuality and Dialectics of the Self in Barnes's The Sense of an Ending and in Tolstoy's Anna Karenina
}

\author{
Elena Bollinger
}

School of Arts and Humanities, University of Lisbon, Lisbon, Portugal

Copyright $\mathrm{C} 2018$ by authors, all rights reserved. Authors agree that this article remains permanently open access under the terms of the Creative Commons Attribution License 4.0 International License

\begin{abstract}
The article examines the literary relationship between The Sense of an Ending and Anna Karenina. Following Kristeva's definition of intertextuality, resting upon the complex dialogic way in which words become intertwined in a literary work of art, it pursues the analysis of permeability of a literary act. The comparative reading process of The Sense of an Ending and of Anna Karenina brings to light the importance of the dialogical principle present in these texts, both in structural and thematic terms. The sense of strangeness or unfathomability involved in the encounter with otherness arises questions about the epistemological nature of the cultural web that constitutes uniqueness. The evocation of the self and of alterity announced in the element of unfamiliarity and resistance in its confrontation with the other helps us to penetrate deeper into the realm of subjectivity. The relationship of The Sense of an Ending to Anna Karenina, revisited in this article, rests upon comparative analysis of discursive practices employed in both texts. The analysis describes a host of symbolic ways in which The Sense of an Ending exploits consciousness and ideas from Anna Karenina, setting up reader's perception that the creation of literary texts arises mostly from the permanent contact of these texts with prior texts. Emphasizing Bakhtin's [1] idea that this contact is "a dialogic contact between several literary works of art" (p.162), the article reflects on different communicative practices, including both the identification of literary sources and the anticipation of future meditations on reading a sense of literary memory as observed in these texts. Specifically, revisiting philosophical reflections on the sense of a self, proposed in Anna Karenina, The Sense of an Ending achieves a connection between personal and collective levels in a process by which literary memory exploits the issue of identity.
\end{abstract}

Keywords Intertextuality, Barnes, Tolstoy, Literary Memory, Identity

\section{Introduction}

The article claims that the concept of intertextuality, described by Genette [9] as "the textual transcendence of the text" (p.1), may be very inspiring for a literary analysis of Julian Barnes's novel The Sense of an Ending. The Russian point of view revisited in this work invites the reader to look not only at a dialogic way of building relationships among texts but also at the reflexive dimension of a discursive practice responsible for the non-linear, ambivalent, process involved in the construction of a literary memory. Bakhtin's definition of dialogism, primarily concerned with the relation of every utterance to other utterances, is expanded by Kristeva's emphasis on the existence of a rather disturbing multiplicity of meanings evoked in the discursive construction of a self. According to her, the relations between the exchanges of a dialogue in a literary work of art are closely connected with the relations established between the discourse of the other and the discourse of the I.

"The literary word is an intersection of textual surfaces rather than a point (a fixed meaning), as a dialogue among several writings", writes Julia Kristeva [11] in Desire in Language (p.65). Defining intertextuality, she first considers the complex dialogic way in which words become intertwined in a literary text. She specifically acknowledges the existence of an intrinsic communicative capacity inherent to literature, so far as a literary text creates meanings due to the constructive and deconstructive practices which it constantly carries. Following Tolstoy's reflections on the communicative side of a literary work of $\operatorname{art}^{1}$, Kristeva's analysis provides an

\footnotetext{
1 In What is Art?, Tolstoy describes art as a supreme form of communication between human beings: "Art is a human activity, consisting in this: that one man consciously, by means of certain external signs, hands on to others feelings he has lived through, and that other people are infected by these feelings, and also experience them. [...]. Evidently such people were wrong in repudiating all art, for they denied that which cannot be denied, one of the indispensable means of communication, without which mankind could not exist" (40-41).
} 
idea of a dynamic interplay established among several writings. In Semeiotike, for instance, she emphasizes the concept of "translinguistic transfer', disclosing the idea of permeability of a literary text. This idea rests upon the existence of a productive dialogue a literary work of art establishes with other literary texts and contexts. Kristeva recognizes the neutralizing ability of a literary text, derived from an aesthetic principle of dialogic junction of words, both constructive and deconstructive. According to Kristeva [12], a literary act is built upon a constant (auto) reflexive dimension, in which the neutralization of meaning emerges from its communication not only with other literary texts, but also with the distinct historical, cultural and literary contexts. Consequently, she states:

To make language an operator at work in the materiality of that which, for society, is a means of contact and understanding, does this not make of it immediately an outsider to language? The so-called literary act, by dint of its not admitting to an ideal distance in relation to that which it signifies, introduces radical otherness in relation to what language is claimed to be: a bearer of meanings. Strangely close and intimately foreign to the substance of our discourse and dreams, literature today appears to be the very act which grasps how language works and signals what it has the power tomorrow to transform (p.9).

Kristeva's meditations on intertextuality suggest a sense of continuity over time, for each single text may always be replicated and reinvented in more ways than one. It is also true, however, that the acknowledgement of a variety of discursive practices, involved in the narrative construction of a self and perceived as fractured, multiple and episodic, rather than continuous, reminds us of other methods for conceptualizing the process of literary memory. The capacity of a work of art to raise new responses situates a process of literary memory on a cross-road between repetition of what is considered as already existing and a stimulus for a constant change and renovation, embodied in a new cultural and historical context.

\section{Materials and Methods}

The literary analysis presented in this article is based on the ongoing academic research in the field of intertextuality in Julian Barnes. Talking about the idiosyncrasies of literary art and a writer's ability to connect life and art, Barnes [7] acknowledges his fascination with the great names of world literature, such as Shakespeare, Flaubert, Turgenev and Tolstoy. Further, he relates his own experience of reading Tolstoy, as follows: "I'm more weary of art in the service of an idea than I am of art that tends to go off to the ultra-bouts spectrum of things. You can see things going wrong with Tolstoy, you can see how the need to propagandize seeps into him as the years go by, and I think that is a warning" (p.145). The interest to further explore Barnes's insightful meditations on Russian literature and culture of the XIX century stays as a main stimulus for the current research project. This article aims to demonstrate one among many other perceptible dimensions of Russian intertextuality in Barnes's works. Reflecting on the thematic and compositional framework upon which The Sense of an Ending rests, the article proposes to revisit a series of complex, ambivalent intertextual processes responsible for "the orientation of the now-said to the already-said and the to-be-said...comprehending all of the ways that utterances can resonate with other utterances and [constitute] consciousness, society and culture" (Bauman, p.5). The theoretical support for this investigation first emerges from the already mentioned Kristeva's concept of neutralization and permeability of a literary act. Further, it focuses on Bauman's [5] understanding of literary performance as "a mode of communicative display" (p.9). He regards intertextuality not simply in terms of "relational nexus between texts, but in how it is accomplished in communicative practice, including both production and reception, and to what ends" (p.5). In terms of discursive practice, the communicative impetus, resulting from the context of a creative dialogue established among different texts, potentiates, according to Bauman [5], not only entextualization (the organization of discourse into a text) but also the iterability of texts, an aesthetic quality inherent to literature. Thus, for instance, Bauman [5] states:

A text, then, from this vantage point, is discourse rendered decontextualizable: entextualization potentiates decontextualization. But decontextualization from one context must involve recontextualization in another, which is to recognize the potential for texts to circulate, to be spoken again in another context (4).

Finally, Orr's [13] reflections on influence and imitation, which she designates as conceptual shadowlands to intertextuality, are employed to shed light on how a communicative act, performed in The Sense of an Ending, transcends the first-layer textual narrative structure and directs itself towards a deeper narrative level, resting upon what Bakhtin [1] calls "a contact of personalities and not of things" (p.162).

\section{Discussion}

The idea of otherness, mentioned in the Introduction, provides a fertile theoretical background for one of the possible readings of Julian Barnes's novel The Sense of an Ending. According to Bauman [5], the recounting of the event as a story may "emerge from multiply embedded acts of contextualization in which talk is oriented to other talk" (p.28). From the structural point of view, the novel builds upon Tony's retrospective reminiscences of his youth, materialized through evoking the relationship with his three schoolmates and the girlfriend Veronica. In aesthetical terms, this relationship is recorded mostly 
through the constructive dialogue among Tony's intimate, emotionally conceived, reflections on life and the meditations on serious philosophical questions embodied in the school context and in his conversations with Veronica. Following the idea of permeability of a literary act provided by Kristeva, the reader may acknowledge the importance of a dialogical principle in The Sense of an Ending, both in structural and thematic terms. Thus, for instance, at the very beginning Tony reflects upon the non-linear relationship established between life and fiction, which ironically becomes, some steps further, a foundational stone for his own memory process:

This was hopeless. In a novel, Adrian wouldn't just have accepted things as they are put to him. What was the point of having a situation worthy of fiction if the protagonist didn't behave as he would have done in a book? Adrian should have gone snooping, or saved up his pocket money and employed a private detective; perhaps all four of us should have gone off on a Quest to Discover the Truth. Or would that have been less like literature and too much like a kid's story? (p.16).

Furthermore, he questions the reliability of the process of memory by which his life events have been recorded: "Again, I must stress that this is my reading now of what happened then. Or rather, my memory now of my reading then of what was happening at the time" (p.41).

Second, though the narrator's voice - which is assumed, from the very beginning, to be Tony's voice - seems to guide the reader through the whole memory process represented in the novel, it is nevertheless progressively balanced by the restructuring of his memories through the systematic dialogue with the other. The ready-made discourse used by Tony to recount his life story carries both decontextualizing and recontextualizing processes. As Bauman [5] mentions, the "extracting ready-made discourse from one context and fitting it to another are...essential mechanisms of social and cultural continuity" (p.8). Tony acknowledges the conceptual importance of corroboration in the process of reconstruction of memory of one's individual life:

What you fail to do is look ahead, and then imagine yourself looking back from that future point. Learning the new emotions that time brings. Discovering, for example, that as the witnesses to your life diminish, there is less corroboration, and therefore, less certainty, as to what you are or have been. Even if you have assiduously kept records - in words, sound, pictures - you may find that you have attended to the wrong kind of record-keeping (p.59).

Thus, a first-person account provided by Tony rests upon a dialogically split into two structure of how things may really happen and how they are remembered - then and now. Consequently, these dichotomic memory dimensions - the objective recording of what happened, on the one hand, and, on the other hand, what and how we emotionally remember what has happened - are perceived, in the text's structure, not as incompatible, but rather as complementary qualities. It seems relevant to mention, also, that the whole memory process is built upon their mutual permeability:

The time-deniers say: forty's nothing, at fifty you're in your prime, sixty's the new forty, and so on. I know this much: that there is objective time, but also subjective time, the kind you wear on the inside of your wrist, next to where the pulse lies. And this personal time, which is the true time, is measured in your relationship to memory. So when this strange thing happened - when these new memories suddenly came upon me - it was as if, for that moment, time had been placed in reverse. As if, for that moment, the river ran upstream (p.122).

The presence of otherness becomes an essential narrative element through which the novel's communicative process, disclosing the elusive nature of self-knowledge, takes place. Reflecting upon the process of self-discovery reworked through memory, Tony Webster questions not only the sense of evasiveness attached to our perception of truth, but also recognizes the importance of corroboration by the other in evaluating the sense of authenticity attached to his personal life story. As a consequence, the dialogic principle, here perceived as an exchange of memories between I and the other, turns into one of the most valuable structuring elements in a personal account of events embodied in this narrative. Contemplating a complex memory process by which he records the past, Tony recognizes the importance of witnesses, as a key element in reconstructing memory. Regretting the fact that "the witnesses to our lives decrease, and with them our essential corroboration" (p.97), the main character nevertheless progressively seeks support for his memories in other people's accounts and testimonies to his own life. Thus, the apparently bifurcated structure of The Sense of an Ending, oscillating between the factual certainties of what happened in the past and the emotionally structured present narration of the past colored by revisionism, turns into a circular experiencing of life events. These are being constantly registered and modified, constructed and reconstructed by the sense of a renewed birth taking place inside Tony's mind. Following Kristeva's idea of a neutralizing ability of a literary act, the birth / ending, as well as life / death dichotomy appears to be recreated into complementary narrative devices in a process of life recollection: "To die when something new is born - even if that something new is our very own self?" (p.105) [my italics]. This question stays, deliberately, unanswered in The Sense of an Ending. Nonetheless, it provides the reader with the essential tools to further explore the semantic intricacies of intertextual processes on which the novel rests. Following Kristeva's principle of permeability of a literary text, and also her above mentioned affirmation of how "literature today appears to be the very act which grasps how language works and signals what it has the power tomorrow to transform", let's turn for a moment to a wider intertextual context which this novel embraces. Ensuing the already mentioned 
corroborative process responsible for the structural development of both novels, and the relations between the exchanges of ideas between them, it would be necessary to consider the following reflection on the sense of an ending / birth proposed by Levin in Anna Karenina:

He knew and felt only that what was taking place was similar to what had taken place the previous year at the deathbed of his brother Nikolay in the hotel of the provincial town. But that had been grief, whereas this was joy. But that grief and this joy both lay equally outside all of life's usual conditions, and were like apertures in this ordinary life through which something higher could be glimpsed. What was taking place was proceeding equally painfully and agonizingly and, as it perceived this higher something, his soul was ascending equally incomprehensibly to a height it had never understood before and with which his intellect could no longer keep pace (p.715) [my italics].

In order to further pursue one of the available intertextual lines of thought in The Sense of an Ending and in Anna Karenina, we will start by evaluating the significance of a repetitive occurrence of the word "something" in the above quoted passages. Following Kristeva's definition of the concept of intertextuality, proposed in "Word, Dialogue and Novel" [11] and stating that "the literary word is an intersection of textual surfaces rather than a point (a fixed meaning), as a dialogue among several writings" ( $\mathrm{p} .65$ ), the presence of the strategically employed word 'something' becomes a textual key device establishing a productively permeable communicative process between these two accounts of personal experience. Oxford English Dictionary [14] defines "something" as "a thing that is unspecified or unknown" or as "used in various expressions indicating that a description or amount being stated is not exact".

This definition of the word 'something' provides a fertile background for analyzing the elusive sense of a self, experienced by Tony in The Sense of an Ending and by Levin in Anna Karenina. Analyzed separately, the construction of the sense of a self, occurring in both novels, rests upon the idea of corroboration between the main character's mind and the uncanny sense of otherness, coming from other characters with whom Tony and Levin communicate. Though the above cited quotations, built on free indirect speech, provide rich psychological accounts of selfhood, the full appreciation of its narrative intensity and of its stylistic complexity only becomes possible when those are balanced against the access to the other character's minds. Again, the sense of corroboration pursues an apparently dichotomic structural principle, oscillating between life and death. Even when it is processed by one's individual mind, it is also fore- and backgrounded by the uncanny, neutralizing, power provided by otherness. As Helena de Paiva Correia [8] points out,

The accepted English translation of Freud's German expression unheimlich is uncanny (217). Yet, according to Sigmund Freud's essay, the word heimlich (familiar, in English) covers two different concepts: something familiar, agreeable, but also that which is concealed and kept out of sight. Further on, the author reminds us that Schelling points out that the antonymous word, unheimlich conveys the meaning of what should have remained secret and hidden but has come to light (p.362).

Thus, the presumably "fixed meaning" of the word "something' as "a thing that is unspecified or unknown" acquires the dynamic coloring produced by a dialogical relationship with the uncanny the word "something" establishes within and outside each novel's textual surface. Considering the subtle yet profound way in which creative writing communes with life, Barnes pays homage to Flaubert, praising his aesthetic capacity to "wade into life as into the sea but only up to the belly button"2. Stating that it is to fiction that we regularly and gradually turn for the truest picture of life, Barnes himself looks forward to exploring the intimate recesses of a feeling arising within the subject as from outside it. It becomes evident that in both The Sense of an Ending and Anna Karenina, the occurrence of a word 'something' aims at encouraging the reader to access the intricacies of the existential quest for self-knowledge, even if still undefinable, pursued by its characters; furthermore, when evaluated on a broader intertextual level, 'something' in The Sense of an Ending enters into complex collaborative relationship with 'something' depicted in Anna Karenina. This corroboration rests upon the conceptual similarity encoded in the word "something" and represented in both texts. Revisiting the territory of what presumably should have remained concealed and kept out of sight, as unspecified or unknown reality, 'something' comes to life as a strong, pure and authentic feeling of a self. Its nature remains inaccessible by reasonable thinking, as both texts show. This feeling of a self does not refer, however, only to subjective self-perception. It seems to encompass an infinitely broader scope of the self. A diversity of cultural meanings which can make for its imprecision and inconsistency relates to the way in which an individual's perception of the world is permanently negotiated by the constantly changing array of overlapping, and often contradictory, experiences embodied in the course of his or her living. As Sebastian Groes and Peter Childs [10] mention, "to portray Barnes primarily as a relativist would do insufficient justice to the seriousness and intellectual intensity of the writer's engagement with the world beyond the subjective self" (p.3). It seems relevant to mention, therefore, that both Barnes and Tolstoy try to construct their characters in terms of otherness and singularity, located somewhere between intimacy and strangeness involved in the perception of their own selves. Thus, for

\footnotetext{
${ }^{2}$ See Conversations with Julian Barnes, 2009, (p.80).
} 
instance, Tony observes that "life isn't just addition and subtraction. There's also the accumulation, the multiplication, of loss, of failure. Adrian's fragment also refers to the question of responsibility: whether there's a chain of it, or whether we draw the concept more narrowly" (p.104). In Anna Karenina, for instance, the still unfamiliar nature of the self is perceived by Levin in a form of a conflict between its conscious and unconscious dimensions:

What was happening to him now was not like what had gone on with his previous states of contrived serenity, when it was necessary to retrace his entire train of thought in order to locate the feeling. On the contrary, the feeling of joy and serenity was now more vivid than before, and his thoughts could not keep up with his feelings (p.818).

The impossibility to verbalize the overwhelming feeling proves to be of a great importance in Tolstoy's poetics. Not only does it reveal the existence, according to Tolstoy's thoughts, of the ungraspable state of communion in which all human beings may remain through the law of goodness, it also recognizes the undefinable territory in which his own being is permanently united with other people's beings, for "understanding of goodness...always has been and always will be the same for everyone" (p.821). Levin reflects upon the invisible sense of union he experiences with other human beings as a revelation, "which I feel within myself, and through recognition of which I do not so much unite, but am united with, other people" (p.820).

The invisible side of a being, united with other people's beings, remains objectively inexplicable, throughout the texts, but its uncanny dimension comes to light and becomes perceived only by a character's inner self.

Thus, "the dialogue among several writings", as defined by Kristeva, is established on a productively permeable intertextual level: both textual surfaces, in which 'something' is repeated, refer to the complementary sense of selfhood depicted in conceptually dichotomic concepts, such as beginning and ending, life and death, singularity and otherness. According to Tolstoy's poetics in general, life only becomes fully perceptible through its eminent contact with death. Moreover, Tolstoy [17] acknowledges that "life is a constant process of dying. And by saying 'I'm constantly dying', one might just as well say I live" (51:15). Barnes's reflections on death appear frequently been shaped up by a rather ironical approach to life:

Fear of death replaces fear of God. But fear of God - an entirely sane early principle, given the hazard of life and our vulnerability to thunderbolts of unknown origin - at least allowed for negotiation. We talked God down from being the Vengeful One and rebranded Him the Infinitely Merciful; we changed Him from Old to New...We can't do the same with death. Death can't be talked down, or parlayed into anything; it simply declines to come to the negotiating table... 'Death is not an artist': no, and would never claim to be one. Artists are unreliable; whereas death never lets you down, remains on call seven days a week, and is happy to work three consecutive eight-hour shifts (Nothing to be Frightened of, p.69-70).

Thus we see that both in The Sense of an Ending and in Anna Karenina "something", though still undefinable and intellectually ungraspable, becomes an important structuring element in the detailed depiction of an interior emotional process of memory directed towards self-discovery. Within the domain of intertextuality, which in Kristeva's terms stresses the importance of permeability and neutralization of a literary act, there are, again, many types and degrees to creative reworking. In both quotations, 'something' occurs precisely when life and death are epistemologically confronted. The symbolic encounter between these two dimensions of the human condition brings several other philosophical questions which can be revisited on a wider intertextual level. This point of view turns into an important theoretical device when approaching a correlation between life and death in the complex narrative structure of both texts. To begin with, it goes almost without saying that both The Sense of an Ending and Anna Karenina enrich their structural and thematic dimensions through approaching, dialogically, the question of suicide. It may even be argued that the idiosyncrasy of the narrative exteriorization of suicide turns, on a first-layer narrative structure, into the central thematic and compositional device in both texts. Moreover, in The Sense of an Ending the theme of suicide appears strategically stated at the very beginning, when Adrian curiously evokes Camus's opinion that suicide is the only true philosophical question (p.13). Though provoking immediate counter response from his fellow friend, who declares the equal importance of "ethics and politics and aesthetics and the nature of reality and all the other stuff" (p.13-14), Adrian's answer stays firm: "The only true one. The fundamental one on which all others depend" (p.14). Taking a deeper step into intricate textual web, this approach to suicide seems to foreground Adrian's naturally conceived response to his own life's complexity. Adrian's suicide is discursively constructed as a well-thought action, involved in the narrative context of his deep philosophical reflections on a sense of human existence. The tragicomic meditation on the nature of human life, foreshadowed by the character's attachment to intellectual freedom and liberal thinking, encourage him to feel free to renounce it. Staying at the very beginning of the narrative development, Adrian's consideration of suicide as the only true philosophical question allows Tony Webster later on to recognize the existential complexity of such an affirmation and to reflect, in a different light, on the significance of his friend's death:

So I doubt anyone paid much attention to Adrian's argument, with its references to philosophers ancient and modern, about the superiority of the intervening act over the unworthy passivity of merely letting life happen to you...He also asked to be cremated, and for his ashes to be scattered, since the swift destruction of the body was also a 
philosopher's active choice, and preferable to the supine waiting for natural decomposition in the ground (49-50).

Let us turn now towards Levin's reflections on the philosophical complexities the existential dimension of human life seems to bear. The identity issue displays an intense cross-referential reflection on the unresolved mystery of life and death in Levin's mind. It establishes a quite perceptible proximity to the core question towards life meaning unveiled in Adrian's suicide:

From the moment when the sight of his beloved dying brother had caused Levin to look for the first time at the issues of life and death through the prism of those new convictions, as he called them, which between the ages of twenty and thirty-four had imperceptibly replaced the beliefs he had held in his childhood and youth, he had been horrified not so much by death as by life, lacking the slightest knowledge about where it came from, what it was for, why it existed, and what it was. The human organism, its destruction, the intractability of matter, the law of the conservation of energy, and evolution were the terms which had replaced his former beliefs. These words and the concepts associated with them were very good for intellectual purposes, but as a guide to life they offered nothing... (p.790).

This passage represents, in the novel, the already well depicted symbolic tension between intellectual reasoning and the full perception of the significance of human existence which reason is unable to explain. The reason which "made knowledge of what he needed to know impossible" foregrounds, in Levin's case, the permanent struggle between the materialistic explanation of the self and the quest for spiritual self-discovery. The way these questions are approached, in The Sense of an Ending as in Anna Karenina, plays a crucial role in understanding the cross-referential function of suicide as represented in these novels. In Adrian's case, the commitment of suicide rests upon the idea of reasonable power over one's individual life, culminating in the sense of control and irreducible liberty over one's own existence. When dialogically confronted with Levin's restrain from committing suicide, the reasonable thinking goes to the second plan, being substituted by "something" ungraspable which permits him to live:

Reasoning had led him into doubt, and prevented him from seeing what should and should not be done. When he did not think, however, but lived, he was constantly aware in his soul of the presence of an infallible judge determining which of two possible courses of action was better and which was worse; and as soon as he did not act as he should have done, he was immediately aware of it.

Thus he lived, neither knowing nor seeing any possibility of knowing what he was and what the point of his life on earth was, and while he was tormented by this lack of knowledge to such a degree that he was afraid of committing suicide, he was at the same time resolutely carving his own particular decisive path in life (p.795-796).
Approximating Adrian's and Levin's reflections on the issue of identity, it becomes evident that the core question for preserving or renouncing life is strictly bounded, in these texts, with a topic of reason and intellectual thinking. Reason assumes the role of a strong intertextual linking device between two texts, playing a role of a common contextual background, which allows The Sense of an Ending to communicate with Anna Karenina. Accessing the polemical fragment of Adrian's diary exposing his last thoughts on life and the individual sense of responsibility, Tony acknowledges his friend's intellectual capacity for rational thinking, as the main impetus for committing suicide:

And how admirable he remained. I have at times tried to imagine the despair which leads to suicide, attempted to conjure up the slew and slope of darkness in which only death appears as a pinprick of light: in other words, the exact opposite of the normal condition of life. But in this document - which I took, on the basis of this page, to consist of Adrian's rational arguing towards his own suicide - the writer was using light in an attempt to reach greater light. Does that make sense? (P.86-87).

Moreover, Tony continues to pursue an attempt to understand, reasonably, Adrian's motifs for committing suicide, taking almost for granted the fact that his friend's uncommon intelligence provides him with the necessary intellectual tools for taking control over his own existence. Whereas Levin's lack of reasonable explanation for what he was living for gives him the possibility to continue living and applying to every life's mystery an instinctively "given knowledge of what is good and what is bad", Adrian's "applied [to life's meaning] intelligence" and reasonable thinking drives him towards death, perceived by his mind as a form of liberation from the "unsought gift" offered by life:

I did, eventually, find myself thinking straight. That's to say, understanding Adrian's reasons, respecting them, and admiring him. He had a better mind and more rigorous temperament than me; he thought logically, and then acted on the conclusion of logical thought. Whereas most of us, I suspect, do the opposite: we make an instinctive decision, then build up an infrastructure of reasoning to justify it (p.53)...Not just pure, but also applied intelligence. I found myself comparing my life against Adrian's. The ability to see and examine himself; the ability to make moral decisions and act on them; the mental and physical courage of his suicide. ...Adrian took charge of his own life, he took command of it, he took it in his hands - and then out of them. How few of us - we that remain - can say that we have done the same? We muddle along, we let life happen to us, and we gradually build up a store of memories (p.88).

Levin's quest for self-discovery, precisely when oscillating between reasonable thinking and the attachment to the ungraspable perception of his self in time, which reason cannot explain, rests upon the balancing nature of "the answer given to [him] by life itself"; presuming that 
"what reason discovered was the struggle for existence and the law demanding that I strangle all those who obstruct the satisfaction of my desires", and that it "could never discover loving one's neighbor, because that is something unreasonable", Levin, by paying attention to his soul, comes towards restraining even more the sense of his disengagement with life. Following Tolstoy's own conclusions on life's meaning ${ }^{3}$, Levin manages to counter-balance his interior contradictions by the laws of almost instinctive perception of goodness:

After grasping clearly for the first time back then that there was nothing ahead but suffering, death, and eternal oblivion for every person, including himself, he had made his mind that he could not live like that, and that he must either explain his life in such a way that it did not appear to be the evil mockery of some kind of devil, or shoot himself. But he had done neither, and had instead gone on living, thinking, and feeling, and had even gone and got married during that very time and experienced many joys, and was happy when he was not thinking about the meaning of his life (p.801).

Analyzing Anna's psychological struggle between life and death depicted in a moment of suicide, it becomes almost self-evident that the narrative process, disclosing her contradictory meditations on the meaning of life, can only be fully grasped by seeing the reverse side, personified by Levin. In her Introduction to Anna Karenina, Rosamund Bartlett mentions the paradox of Tolstoy writing with such sympathy about Anna while at the same time writing a novel which clearly condemns adultery 4. Evidently, Anna's gradual self-destruction followed by suicide stays as a symbolic shadowland to Levin's instinctively perceived family happiness. Curiously, the moment in which Anna commits suicide follows the rationally conceived desire of vengeance she is giving to herself as a fact of justifying her action:

And suddenly, remembering the man who had been crushed on the day she had first met Vronsky, she realized what she had to do...'There!' she said to herself, looking down into the wagon's shadow at the mixture of sand and coal sprinkled on the sleepers; 'there, right at the midpoint, and I'll punish him and be rid of everybody and myself' (p.770).

\section{Conclusions}

It becomes clear how The Sense of an Ending and Anna Karenina pursue similar narrative developments which in turn propose a permeable, complementary, account of

\footnotetext{
${ }^{3}$ In the unsent letter to Strakhov, Tolstoy mentions the importance of the other in perceiving oneself: "The other is more visible than oneself. And I see you clearly...And it is impossible for you to write your life story. You don't know what is good and what is bad in it. And one needs to know" (November 19-22, 1879; quoted in Paperno, 53)

4 For more details, see Bartlett's Introduction to Anna Karenina.
}

one's life experience. Both texts are built upon the intricate depiction of its main character's quest for the sense of identity. Both Tony's and Levin's search for identity are fore- and backgrounded by the uncanny sense of otherness, perceptible through the careful representation of other character's inner selves.

Tony's acknowledgement of a fragment from Adrian's diary partly explaining his friend's reasons for committing suicide allows him to go further in evaluating the reliability of his own memories questioning the accuracy of chronological time when confronted with emotionally perceived sequences of events. Both texts are built upon dialogically conceived reflections on time, memory and identity, doing justice to Kristeva's definition of intertextuality. In Intertextuality, Debates and Contexts, Mary Orr pursues multidimensional theoretical line of the analysis of intertextuality. Instead of considering it as a key-concept in a rich textual web the post-modernist narrative frequently claims to be, Orr's study looks forward to situating a concept of intertextuality into the broader cultural, historical and literary contexts. According to Orr, such traditionally conceived concepts as creative influence and productive imitation stay permanently as shadowlands to intertextuality. Following Orr's [13] line of thought, these key-concepts still have a capacity to maintain a constructive dialogue between canonical past and the contemporary impetus for innovation ${ }^{5}$ :

Postmodern intertextuality pertains to be all-inclusive of text, including the Bible. Yet its anti-religious spirit of interpretation, that all texts are text, in fact delivers tokenism and taboo packaged together. Influence studies, especially comparative, allow greater space for traditions across historical periods. Cultural tunnel vision or political correctness often airbrush anti-humanitarian parts of culture out of the picture or clothe them more comfortably (177).

Similarly, Julian Barnes considers literary traditions of the past, reflecting on their constructive contribution to modern art in general. In Keeping an Eye Open, Barnes [2] invites his reader to evaluate the dimension of the aesthetical variety coming from the cultural heritage of the past. He claims that modern art continues to stay in a permanent dialogue with the past: "I didn't realize couldn't yet see - how in all the arts there are usually two things going on at the same time: the desire to make it new, and a continuing conversation with the past" (p.9). Moreover, he goes even further in considering the aesthetical contribution of the previous literary movements, highlighting the creative dimension of Realism: "It took me a lot of looking before I understood that Realism, far from being just the base camp for high-altitude adventure by others, could be just as truthful, and even just as strange -

\footnotetext{
${ }^{5}$ See the first three chapters of Mary Orr's Intertextuality, Debates and Contexts (2008).
} 
that it too involved choice, organization and imagination, so in its own way might be equally transformative" (p.7).

Barnes's valorization of the aesthetic background provided by Realism together with Orr's theoretical approach to the creative dimension of conceptual shadowlands coming from the past, invites the attentive reader to put the aesthetical representation of memory as depicted in The Sense of an Ending in a constructive conversation with a literary portrayal of otherness and of a sense of alterity disclosed in Anna Karenina, underlining Kristeva's definition of a way in which literary texts constitute the relations between the exchanges of a dialogue. To sum up, let us turn towards Orr's [13] enriching ambivalence when defining the role of intertextuality in perceiving of literary text:

However, if 'nothing only comes of nothing', goes endlessly round and round or empties out, how can intertextuality's parameters be ascertained? Rather than defining intertextuality by what it is not, for example, against nonsense (the via negative), or, indeed, by a double negative (a deconstruction of deconstruction), this study, like Lear, will press it further for what it is. Lear's personal tragedy in so doing, however, also constitutes a warning. From the outset, his error was to take at face value the wordy reformulations of 'love' of his elder daughters Goneril and Regan, whereas it was his youngest daughter Cordelia's more profound silence that spoke the more. His failure to discern between her 'nothing' as no response, and nothing as something infinitely more than was expressible, is the ultimate tragedy of the play and a timely reminder to debates grounded in linguistics. Terms such as 'love' or 'intertextuality' can be nothing without the qualifiers and contexts in which they can speak again (p.4-5).

\section{Acknowledgements}

I would like to express my gratitude to Professor Luisa Maria Flora, my research supervisor, for her valuable suggestions during the planning and development of this research work.

\section{REFERENCES}

[1] Bakhtin, Mikhail M. Speech Genres and Other Late Essays. Caryl Emerson and Michael Holquist, eds. Vern McGee, trans. University of Texas Press, Austin, 1986.
[2] Barnes, Julian. Keeping an Eye Open. Essays on Art. Random House Canada, 2015.

[3] Barnes, Julian. Nothing to be frightened of. Vintage, London, 2009.

[4] Barnes, Julian. The Sense of an Ending. Vintage, London, 2012.

[5] Bauman, Richard. A World of Others' Words. Blackwell Publishing, USA, 2004.

[6] Childs, Peter. Julian Barnes. Contemporary British Novelists. Manchester University Press, 2011.

[7] Conversations with Julian Barnes. Edt. Vanessa Guignery and Ryan Roberts. University Press of Mississippi, 2009.

[8] Correia, Maria Helena de Paiva. From Heart of Darkness to Apocalypse Now. Imprensa da Universidade de Coimbra. Coimbra University Press. DOI: https://doi.org./10.14195/9 78-989-26-1308-6 17. Accessed: 3-Oct-2018 22:08:44.

[9] Genette, Gérard. (1982). Palimpsests: Literature in the Second Degree. Channa Newman and Claude Doubinsky, trans. University of Nebraska Press, Lincoln, 1997.

[10] Groes, Sebastian and Childs, Peter. Julian Barnes. Contemporary Literary Perspectives. Edited by Sebastian Groes and Peter Childs. Continuum, London and New York, 2011.

[11] Kristeva, Julia. (1980). "Word, Dialogue and Novel”. Desire in Language. A Semiotic Approach to Literature and Art. Edited by Leon S. Roudiez. Translated by Thomas Gona, Alice Jandine and Leon S. Roudiez. Columbia University Press, New York, 64-95.

[12] Kristeva, Julia. (1969). Semeiotikè: recherches pour une sémanalyse. Paris: Points. Translated by Mary Orr in Intertextuality. Debates and Contexts, Mary Orr, 29, 2008.

[13] Orr, Mary. (2003). Intertextuality. Debates and Contexts. Cambridge: Polity Press, 2008.

[14] Oxford English Dictionary, Online available from www.oed.com

[15] Paperno, Irina. Who, what am I? Tolstoy struggles to narrate the self. Ithaca and London, Cornell University Press, 2014.

[16] Tolstoy, Leo. Anna Karenina. Translated by Rosamund Bartlett. Oxford University Press, 2014.

[17] Tolstoy, Leo. Polnoe sobranie sochinenii v 90 tomakh. Complete Collected Works in 90 volumes. Moscow Leningrad, 1928-58. Translated Irina Paperno, in What am I? Tolstoy struggles to narrate the self. Ithaca and London, Cornell University Press, 2014.

[18] Tolstoy, Leo. (1898). What is Art? Translated by R. Pevear and L. Volokhonsky. London, Penguin Books, 1995. 